Zusammenfassung. Zwischen 1944 und 1969 konnten wir 463 Dickdarmcarcinome beobachten. Von diesen hatten wir 247 radikal reseziert und 179 palliativ versorgt. 37 waren zum Teil nicht operabel oder lehnten jeden Eingriff ab.

Die primäre Mortalität betrug $16 \%$ bei den ersterwähnten und $30 \%$ bei den Umgehungseingriffen.

Nach 5 Jahren lebten von den kurativ Operierten nur mehr $23 \%$.

Nur die Früherfassung kann die Prognose verbessern, solange ein optimal wirkendes Cytostaticum fehlt.

\title{
119. Diagnostik und Therapie der familiären Polyposis coli
}

\author{
K. ARnold-Erlangen
}

The Diagnosis and Treatment of Familial Polyposis coli

Summary. The clinical picture of familial polyposis coli is characterized by multiple adenomas in the mucosa of the colon, the tendency of these to show malignant changes at an early age and a dominant pattern of heredity. By careful research into the family history and very early radical surgery, ideal cancer prophylaxis becomes a possibility. Our own observations are based on 11 families with a total of 37 cases of polyposis. Opinions are expressed on the diagnosis, differential diagnosis, the danger of cancer and the treatment (procto-colectomy or ileo-rectal anastomosis). Later observation of the patients and follow-up of the families, with the aid of family-trees and a special card-index of all the operated patients and members of their families, are described.

Zusammenfassung. Das Krankheitsbild der familiären Polyposis coli ist gekennzeichnet durch multiple Adenome der Dickdarmschleimhaut, durch maligne Entartung dieser Polypen in frühem Lebensalter und durch eine dominante Vererbung dieser Erkrankung. Durch sorgfältige Erforschung der Familien und frühzeitige radikale Operation ist eine ideale Krebsprophylaxe möglich. Unsere eigenen Beobachtungen beruhen auf 11 Polyposisfamilien mit insgesamt 37 Erkrankten. Stellungnahme zur Diagnostik, Differentialdiagnose, Krebsgefährdung und Therapie (Prokto-Colektomie oder ileo-rectale Anastomose). Nachuntersuchungen und Weiterverfolgung der Familien anhand der Stammbäume und einer Kartei der Operierten und der Gefährdeten.

Präsident: Ich übergebe nun die Leitung der Diskussion an Herrn Kollegen Linder.

\section{Zusammenfassender Bericht über die Forums-Diskussion}

Diskussionsleiter: F. Linder.Heidelberg

Protokollführer: H. U. Drüner-Heidelberg

Diskussionsteilnehmer: G. Böttger-Schweinfurt, F. Deucher-Aarau/Schweiz, E. Holder-Nürnberg, M. Reifferscheid-Aachen und F. Stelzner-Hamburg

K. Arnold-Erlangen wies in seinem aus Zeitmangel gekürzten Vortrag darauf hin, daß die Rectoskopie zur Erkennung der tamiliären Polyposis das wichtigste Diagnosticum ist. Oberhalb von $30 \mathrm{~cm}$ finden sich keine versteckten Adenome. $50 \%$ der 